\title{
Experiences of coronary intensive care in a district hospital
}

\author{
P. M. MCALLEN \\ M.D., F.R.C.P. \\ Medical Department, West Middlesex Hospital, Isleworth, Middlesex
}

\begin{abstract}
Summary
Seven hundred and twenty-one patients were admitted during 22 months. Recent myocardial infarction was confirmed in 518. In this group, $115(22 \%)$ died in hospital and $33(6 \%)$ were resuscitated and left hospital alive. Prophylactic measures probably prevented cardiac arrest in a number of patients and contributed to lowering the mortality rate. Other factors influencing cardiac arrest and death were sex, age, time after onset of infarction and ECG pattern. Anticoagulants had no influence. The clinical presentation was most varied and several difficult diagnostic patterns are described.
\end{abstract}

MYOCARDIAL infarction is the most common cause for medical admission to the West Middlesex Hospital, and in 1967 four physicians and their junior staff agreed to participate in running an intensive coronary care unit. This unit was sited in one part of an acute medical ward and comprised one four-bed ward for males and two adjacent single rooms for either sex, and this arrangement was found appropriate for the sex incidence of myocardial infarction. The present paper concerns the clinical experience in the treatment of myocardial infarction during the period November 1967 to September 1969. There were 721 patients admitted.

\section{Clinical groups (Table 1)}

(i) Recent myocardial infarction (518 patients).

This diagnosis required a history of recent ischaemic cardiac pain together with an electrocardiogram showing either (a) pathological $Q$ waves plus serial changes in $S-T$ segments and $T$ waves, or (b) serial changes in $\mathrm{S}-\mathrm{T}$ segments and $\mathrm{T}$ waves where they were accompanied by significant and transient elevation of serum enzymes, serum aspartate aminotransferase (SGOT) and alpha hydroxybutyrate dehydrogenase (HBD). If a left bundle branch block pattern dominated the electrocardiogram, this needed to be associated also with serum enzyme changes. In some cases there was the addition of positive necropsy evidence.

(ii) Chest pain not due to recent myocardial infarction (108 patients)

This group included a wide range of conditions.
TABLE 1. Clinical groups, November, 1967 to September 1969 (six beds)

\begin{tabular}{|c|c|c|}
\hline $\begin{array}{c}\text { Recent } \\
\text { myocardial } \\
\text { infarction }\end{array}$ & $\begin{array}{l}\text { Chest pain not } \\
\text { due to recent } \\
\text { myocardic } 1 \\
\text { infarction }\end{array}$ & $\begin{array}{l}\text { Arrhythmias } \\
\text { not due to recent } \\
\text { myocardial } \\
\text { infarction }\end{array}$ \\
\hline 518 & 108 & 95 \\
\hline
\end{tabular}

The most common situation was an episode of recent ischaemic cardiac pain associated with an abnormal electrocardiogram but no evidence of a recent myocardial infarction. This was decided by absence of serial changes in $S-T$ segments and $T$ waves and lack of elevation of serum enzymes tested repeatedly. Such episodes of ischaemic cardiac pain are often labelled prolonged anginal attacks.

(iii) Arrhythmias not due to recent myocardial infarction (95 patients)

This group also had many causes. As an example, there were six patients who presented with AdamsStokes attacks due to complete heart block of the chronic idiopathic type.

\section{Recent myocardial infarction}

This group ( $72 \%$ of the total admissions) was examined in some detail.

\section{Death and resuscitation rates (Table 2)}

The percentages of both are close to those in earlier reports from this country (Lawrie et al., 1967; Jewitt et al., 1967; Thomas, Jewitt \& Shillingford, 1968; Pentecost \& Mayne, 1968).

TABle 2. Death and resuscitation rates. Deaths inc! ude all patients who did not leave hospital alive. Resuscitated petients left hospital alive after a staj of some 3-4 weeks

\begin{tabular}{cccc}
\hline $\begin{array}{c}\text { Recent } \\
\text { myocardial } \\
\text { infarction }\end{array}$ & Deaths & $\begin{array}{c}\text { Resuscitated } \\
\text { patients } \\
\text { leaving } \\
\text { hospital }\end{array}$ & $\begin{array}{c}\text { Prevented } \\
\text { cardiac } \\
\text { arrests }\end{array}$ \\
\hline $\begin{array}{c}518 \\
(4 \mathrm{M}, 1 \mathrm{~F})\end{array}$ & $\begin{array}{c}115(22 \%) \\
(4 \mathrm{M}, 1 \mathrm{~F})\end{array}$ & $\begin{array}{c}33(6 \%) \\
(2 \mathrm{M}, 1 \mathrm{~F})\end{array}$ & $?$ \\
\hline
\end{tabular}


Routine use was made of the usual recommended prophylactic and therapeutic measures for arrhythmias (Thomas \& Woodgate, 1966; Lown et al., 1967; Thomas et al., 1968). It was hoped that these measures prevented the onset of cardiac arrest in an appreciable percentage of patients but no accurate measure was possible. During the years immediately before the Coronary Intensive Care Unit, our hospital mortality was over $30 \%$.

\section{Sex distribution (Table 2)}

The ratio for both incidence and death was almost exactly four male to one female.

As regards successful resuscitation, females were more responsive and three were over 70 years of age.

\section{Age and deaths (Table 3)}

It has been observed that mortality rises with increase of age (Honey \& Truelove, 1957; Lawrie et al., 1967) and our patients showed the same trend.

\section{Time factor in deaths and resuscitation}

It is well known that length of time after onset of myocardial infarction is an important factor as regards the likelihood of death. A community study revealed that for men, $27 \%$ died within $15 \mathrm{~min}$ and $50 \%$ within $3 \mathrm{hr} 30 \mathrm{~min}$ and for women, $22 \%$ died within $15 \mathrm{~min}$ and $50 \%$ within $6 \mathrm{hr} 18 \mathrm{~min}$ (McNeilly \& Pemberton, 1968). Patients who survive
TABle 3. Age and deaths of patients

\begin{tabular}{|c|c|c|c|c|}
\hline \multirow{2}{*}{ Age } & \multicolumn{2}{|c|}{ Males } & \multicolumn{2}{|c|}{ Females } \\
\hline & $\begin{array}{l}\text { No. of } \\
\text { patients }\end{array}$ & $\begin{array}{l}\text { No. of } \\
\text { deaths }\end{array}$ & $\begin{array}{c}\text { No. of } \\
\text { patients }\end{array}$ & $\begin{array}{l}\text { No. of } \\
\text { deaths }\end{array}$ \\
\hline $\begin{array}{l}30-39 \\
40-49 \\
50-59 \\
60-69 \\
70-79 \\
80-89\end{array}$ & $\begin{array}{r}9 \\
52 \\
134 \\
175 \\
41 \\
1\end{array}$ & $\begin{array}{c}2(22 \%) \\
4(8 \%) \\
23(17 \%) \\
48(27 \%) \\
14(34 \%) \\
1(100 \%)\end{array}$ & $\begin{array}{r}- \\
27 \\
27 \\
26 \\
2\end{array}$ & $\begin{array}{l}5(19 \%) \\
8(16 \%) \\
9(35 \%) \\
1(50 \%)\end{array}$ \\
\hline
\end{tabular}

the early minutes and hours after infarction, and who are sent to hospital, will continue this trend of $\vec{\omega}$ early death although at a lessening rate. Most patients who die in hospital do so within the firsto $24 \mathrm{hr}$ and then the number falls each day during the first week (Honey \& Truelove, 1957; Beard et al., 1960; Killip, 1966). Our patients showed the expected hospital time pattern for deaths (Fig. 1). i

It follows that the first few days in hospital give the greatest opportunity for successful resuscitation? from cardiac arrest, especially if due to ventricularc fibrillation associated with little myocardial damage and this proved to be so with our patients (Fig. 2). This is the period also for greatest benefit from prophylactic measures which may prevent the onsetc of cardiac arrest. Thus, a coronary intensive care- unit has its maximum value during the first $48 \mathrm{~g}$ ( after the onset of infarction (Lawrie et al., 1967).

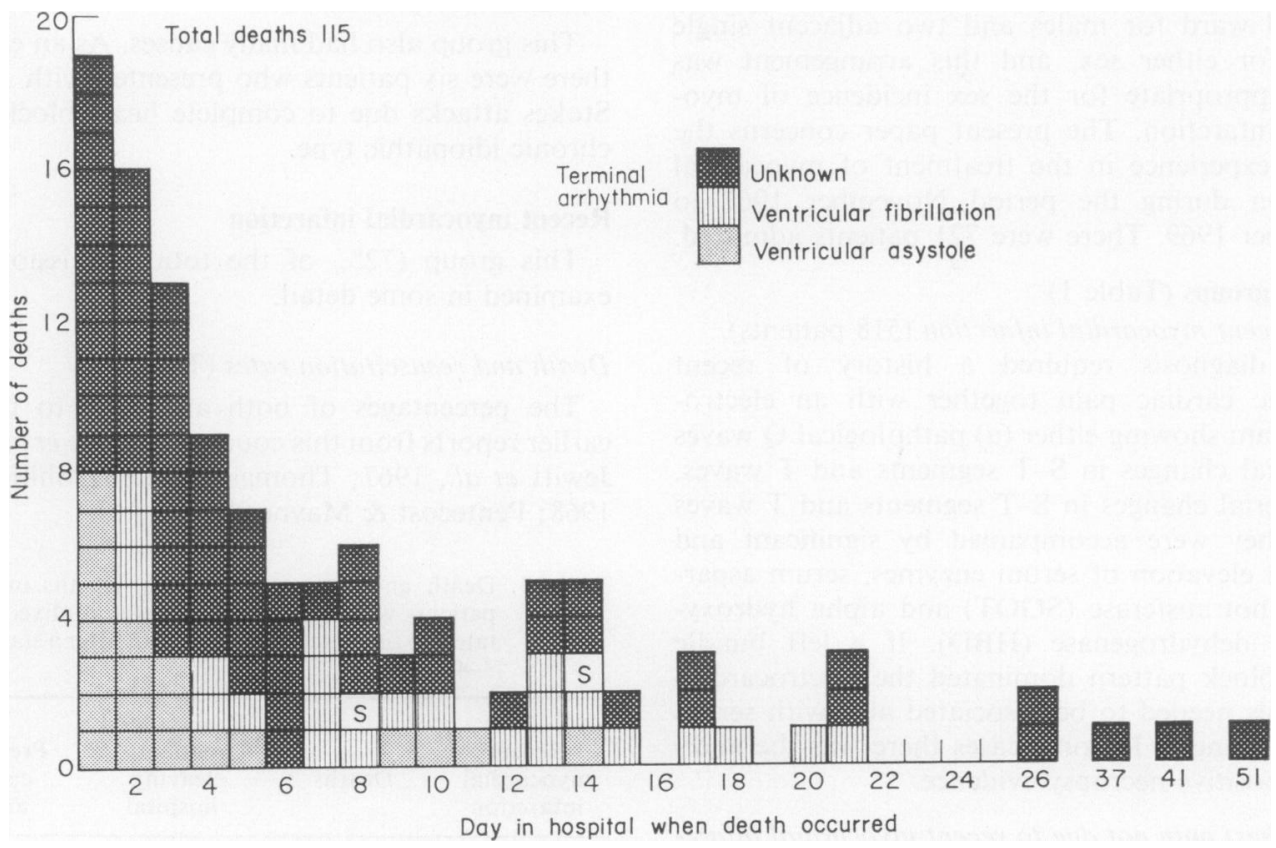

Fig. 1. Hospital time pattern for deaths. $S$ indicates two patients dying in sinus rhythm. Both had rupture of an infarcted left ventricle. 


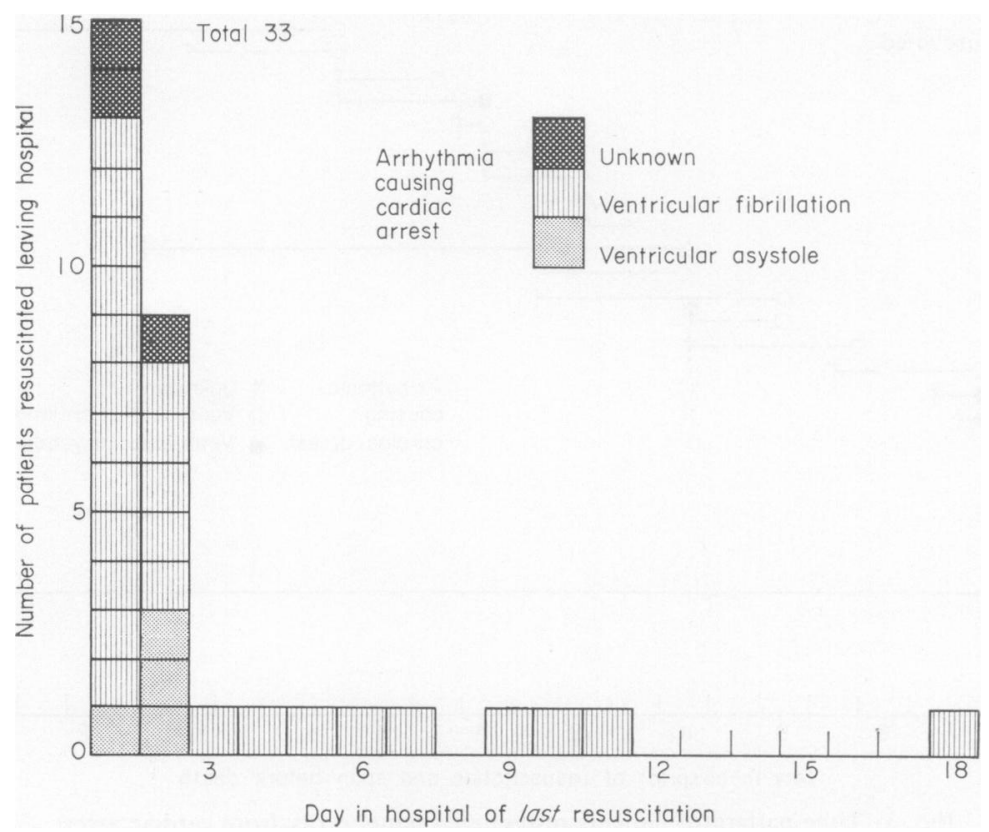

Fig. 2. Successful resuscitation from cardiac arrest. Five patients had two or more episodes of cardiac arrest.

In a coronary intensive care unit most patients who die during the first day do so now from ventricular asystole associated with extensive myocardial damage - a situation which cannot be countered at present (Goble, Sloman \& Robinson, 1966; Lawrie et al., 1967; and our Fig. 1).

A number of patients were resuscitated temporarily from cardiac arrest but eventually died in hospital some hours, days or weeks later (Fig. 3). In half of these patients the time of onset of the first episode of cardiac arrest showed the usual high incidence during the first few days.

Small numbers of cardiac arrests and deaths occurred in our patients on nearly every day of the second and third week in hospital (Figs. 1, 2 and 3). With most of these patients the usual warnings of a possible late cardiac arrest were given during the first few days viz. recurrent chest pain, arrhythmias, hypotension or heart failure (Spracklen et al., 1968). However, in one late death and in three late successful resuscitations, the previous clinical course had been entirely uneventful.

In our Medical Department the average experience of resident doctors has been that for every seven cardiac arrest calls, their efforts have been immediately successful in two and permanently successful in one of these two. This is exhausting and emotional work abruptly superimposed on their busy daily routine.

\section{Time progress of patients into coronary unit}

It is evident that a hospital mortality rate for myocardial infarction will be affected markedly by the time gap between onset of infarction and arrival at hospital (Lown et al., 1967; Pentecost \& Mayne, 1968). Over a period of 6 months progress times were checked on all patients entering our unit. The main interest was in the order of delay occurring within the hospital area. The mean time from Casualty to the Medical Department was 48 min, a figure similar to other busy Casualty Departments. If a patient was markedly ill from a coronary attack, the Ambulance Service bypassed the Casualty Department. Although resuscitation equipment was present in the Casualty Department, correction of cardiac arrest was more likely to be a permanent success if dealt with in the Medical Department. Taking then the Medical Department as our first fully protected area, some $50 \%$ of patients arrived within $4 \mathrm{hr}$ of the onset of myocardial infarction (Table 4). The subsequent

TABLE 4. Time from onset of chest pain to admission to Medical Department (September 1968 to March 1969)

\begin{tabular}{cccccccc}
\hline $1 \mathrm{hr}$ & $2 \mathrm{hr}$ & $3 \mathrm{hr}$ & $4 \mathrm{hr}$ & $5 \mathrm{hr}$ & $6 \mathrm{hr}$ & $6 \mathrm{hr}+$ & Total \\
\hline 5 & 23 & 19 & 32 & 14 & 15 & 49 & 157 \\
$3 \%$ & $15 \%$ & $12 \%$ & $20 \%$ & $9 \%$ & $10 \%$ & $31 \%$ & $100 \%$ \\
$50 \%$ & & & & & \\
\hline
\end{tabular}




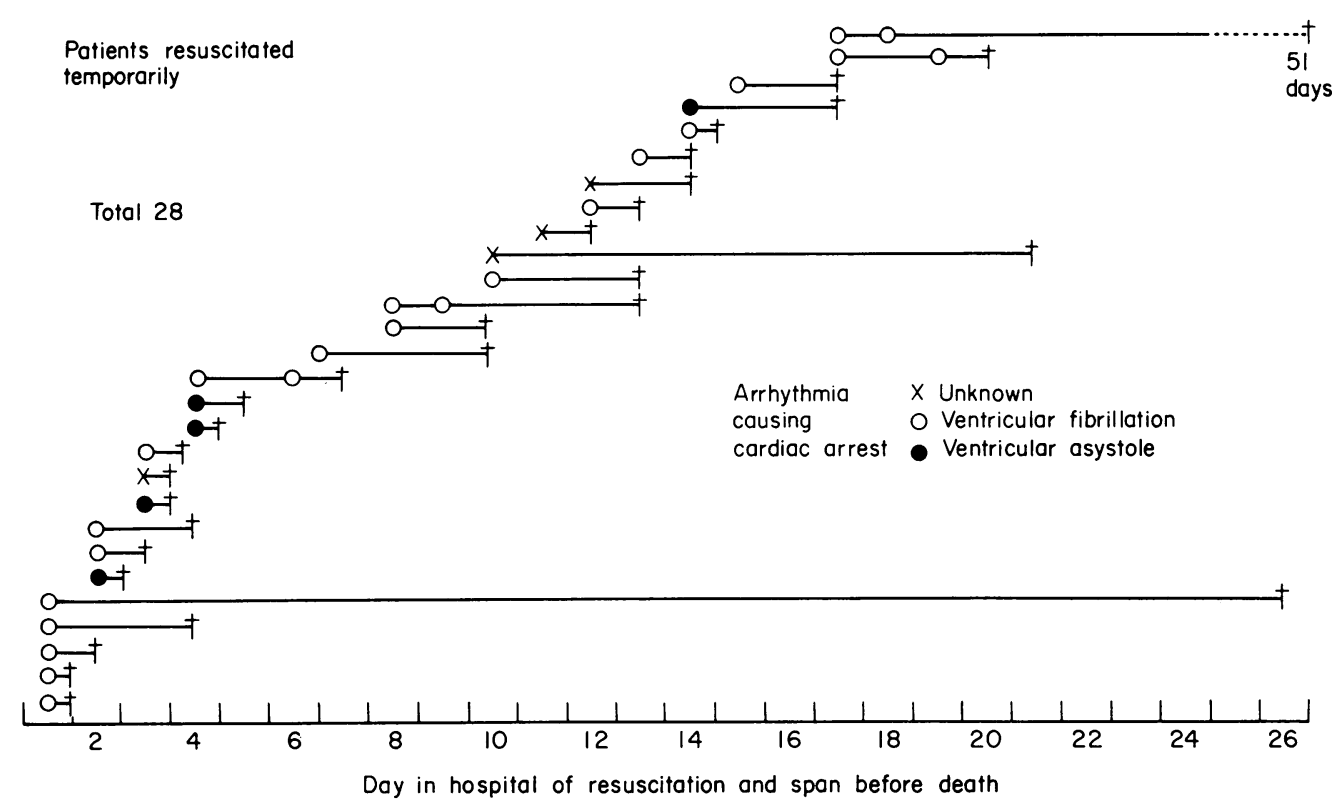

FIG. 3. Time pattern of patients resuscitated temporarily from cardiac arrest.

movement within the Medical Department from emergency ward to Coronary Unit was slow as only $36 \%$ of patients arrived within $1 \mathrm{hr}$ of entering the Department. This delay was usually explained by the ward doctors having to cope with a large number of emergencies at the same time.

\section{Electrocardiogram and prognosis}

The electrocardiograms of the patients with recent myocardial infarction were subdivided on anatomical location and extent (Table 5). Pathological $Q$ waves were interpreted as indicating full thickness transmural infarction. Location of pathological $Q$ waves in inferior, antero-septal or lateral area were suggestive of a recent thrombosis respectively in right coronary, left anterior descending or left circumflex artery.

As would be expected, on general grounds the mortality rate was significantly lower in the sub- $\overrightarrow{0}$ section without pathological $Q$ waves-the partigl or intramural infarction. This type of patient 色惮 some quarters tends to be labelled 'mild coronar and be considered not worthy of admission to a coronary intensive care unit. However, some of these patients did indeed develop cardiac arrest and they were particularly favourable for resuscitation, having $\stackrel{\varrho}{\vec{z}}$ little myocardial damage (Table 5). The newly arrived house physician needs to be encouraged to transfer such patients quickly to the Coronary Unit.

\section{Anticoagulants}

Nearly halfway through the period under review, all the six general physicians concerned agreed to 3 stop the use of routine anticoagulants. Before this change all had used oral anticoagulants routinely for 3 patients with recent myocardial infarction. Details of 0

TABLE 5. Anatomical location and extent of myocardial infarction

\begin{tabular}{lccccc}
\hline & & $\begin{array}{c}\text { Transmural infarction } \\
\text { Pathological Q waves }\end{array}$ & $\begin{array}{c}\text { Intramural } \\
\text { infarction }\end{array}$ \\
\cline { 2 - 5 } & Inferior & Antero-septal & Lateral & Massive & $\begin{array}{c}\text { (ST \& } \mathrm{T} \\
\text { changes } \\
\text { only) }\end{array}$ \\
& $($ Avf) & $\left(\mathrm{V}_{1}-\mathrm{V}_{4}\right)$ & $\left(\mathrm{V}_{5}, \mathrm{~V}_{6}\right.$ Avl) & $\begin{array}{c}\text { (Two or } \\
\text { more areas) } \\
109\end{array}$ & 149 \\
\hline $\begin{array}{l}\text { Deaths } \\
\text { Resuscitation }\end{array}$ & $36(23 \%)$ & $30(34 \%)$ & $6(35 \%)$ & $30(28 \%)$ & $13(9 \%)$ \\
\hline
\end{tabular}


these consecutive admissions before and after the change are shown in Table 6. This was not a properly controlled trial of the effects of anticoagulants, but nevertheless no other major change occurred in routine treatment. It must be noted also that not every patient during the anticoagulant period received anticoagulants as contra-indications were at times present, but this group did give some measure of the effect of the policy of routine anticoagulants applied whenever possible. The various percentages for deaths, resuscitation and complications were almost identical during the two periods.

\section{Complete heart block}

An arrhythmia which caused us much uneasiness was complete heart block. As expected, the incidence was low, being $4 \%$ (Table 7), and this incidence is close to the figure of $5-8 \%$ found by Brown, Hunt $\&$ Sloman (1969). The untreated mortality rate of complete heart block complicating acute myocardial infarction, is within the range of 50-60\% (Paulk \& Hurst, 1966; Epstein et al., 1966). The main therapeutic effort reported is emergency endocardial pacing and a reduction in mortality has been claimed by various authors of $10-15 \%$ or more (Sowton, 1967; Scott et al., 1967; Sutton, Chatterjee \& Leatham, 1968). However, pacing is not without hazard and, as no controlled trial has been conducted on this form of treatment, its true value remains rather uncertain.

In this hospital it is not easy to perform emergency pacing as there is no cardio-thoracic unit with readily available staff practised in such a manoeuvre.

TABLE 6. Details of consecutive admissions using anticoagulants as routine and after stopping the use of anticoagulants

\begin{tabular}{lcc}
\hline & $\begin{array}{c}\text { Nov. 1967 to } \\
\text { Sept. 1968 }\end{array}$ & $\begin{array}{c}\text { Sept. 1968 to } \\
\text { Sept. 1969 }\end{array}$ \\
\cline { 2 - 3 } & $\begin{array}{c}\text { Routine } \\
\text { anticoagulants }\end{array}$ & $\begin{array}{c}\text { No routine } \\
\text { anticoagulants }\end{array}$ \\
\hline Deaths & $48(22 \%)$ & $67(22 \%)$ \\
Resuscitated & $13(6 \%)$ & $20(7 \%)$ \\
Venous-embolism & $16(7 \%)$ & $22(7 \%)$ \\
Systemic-embolism & $2(1 \%)$ & $6(2 \%)$ \\
Rupture and/or & $8(4 \%)$ & $2(1 \%)$ \\
$\quad$ haemopericardium & $132(62 \%)$ & $190(62 \%)$ \\
Arrhythmias & 214 & 304 \\
\hline \multicolumn{1}{c}{ Total } & & \\
\hline
\end{tabular}

TABLE 7. Incidence of complete heart block

\begin{tabular}{cccccc}
\hline \multirow{2}{*}{ Total } & \multicolumn{2}{c}{ Survived } & & \multicolumn{2}{c}{ Died } \\
\cline { 2 - 3 } \cline { 5 - 6 } & No pacing & Pacing & & No pacing & Pacing \\
\hline $23(4 \%)$ & 8 & 2 & & 7 & 6 \\
\hline
\end{tabular}

Therefore, our policy nas been a conservative one of observing or using drugs only unless Adams-Stokes attacks, heart failure or hypotension developed. If one of these complications occurred, and the patient was considered able to travel, he was transferred to Dr Malcolm Towers' cardiological unit at Harefield Hospital for emergency endocardial pacing. If the patient was not fit to travel, we did our best locally at endocardial pacing. Our group of patients, paced and unpaced, had a total mortality of $57 \%$ (Table 7 ).

We look forward to learning from Dr Alan Harris the best way to tackle this problem in a district hospital.

\section{Slow crescendo myocardial infarction}

A situation easy to mismanage was the slow crescendo development of myocardia! infarction which occurred in some of the patients. An example of this was a 59-year-old man working as a tyre inspector (Fig. 4). Three weeks before hospital admission he had ischaemic cardiac pain on effort for the first time whilst at work. A quiet week followed and then a number of further brief ischaemic pains occurred on effort. One week before admission he had $2 \mathrm{hr}$ of ischaemia at rest and this led him to consult his general practitioner. The doctor arranged an electrocardiogram but as this was normal the patient resumed work. After several days the patient visited his general practitioner again complaining of more chest pain at rest. Another electrocardiogram was requested and this was still normal. Shortly, the patient had three bouts of ischaemic pain rapidly during 1 day and his doctor, convinced that he was having a myocardial infarction, arranged hospital admission urgently. On admission the electrocardiogram was still completely normal and remained so when repeated later the same day. The serum enzymes showed one normal result and one borderline level. It was not until 4 days later, with another episode of chest pain, that the electrocardiogram at last became abnormal as did also the serum enzymes.

A case such as this explodes the happy belief that, when a patient has chest pain, if the electrocardiogram repeated after $24 \mathrm{hr}$ is still within normal limits, then a myocardial infarction cannot be impending.

\section{Impending myocardial infarction versus prolonged anginal attack}

A more common problem was the differentiation between an impending myocardial infarction and a prolonged attack of angina in a patient with known coronary artery disease. A 53-year-old housewife illustrated this. After several days of indigestion she developed retrosternal pain whilst walking (Fig. 5). This was followed by a mild chest ache and, as a 


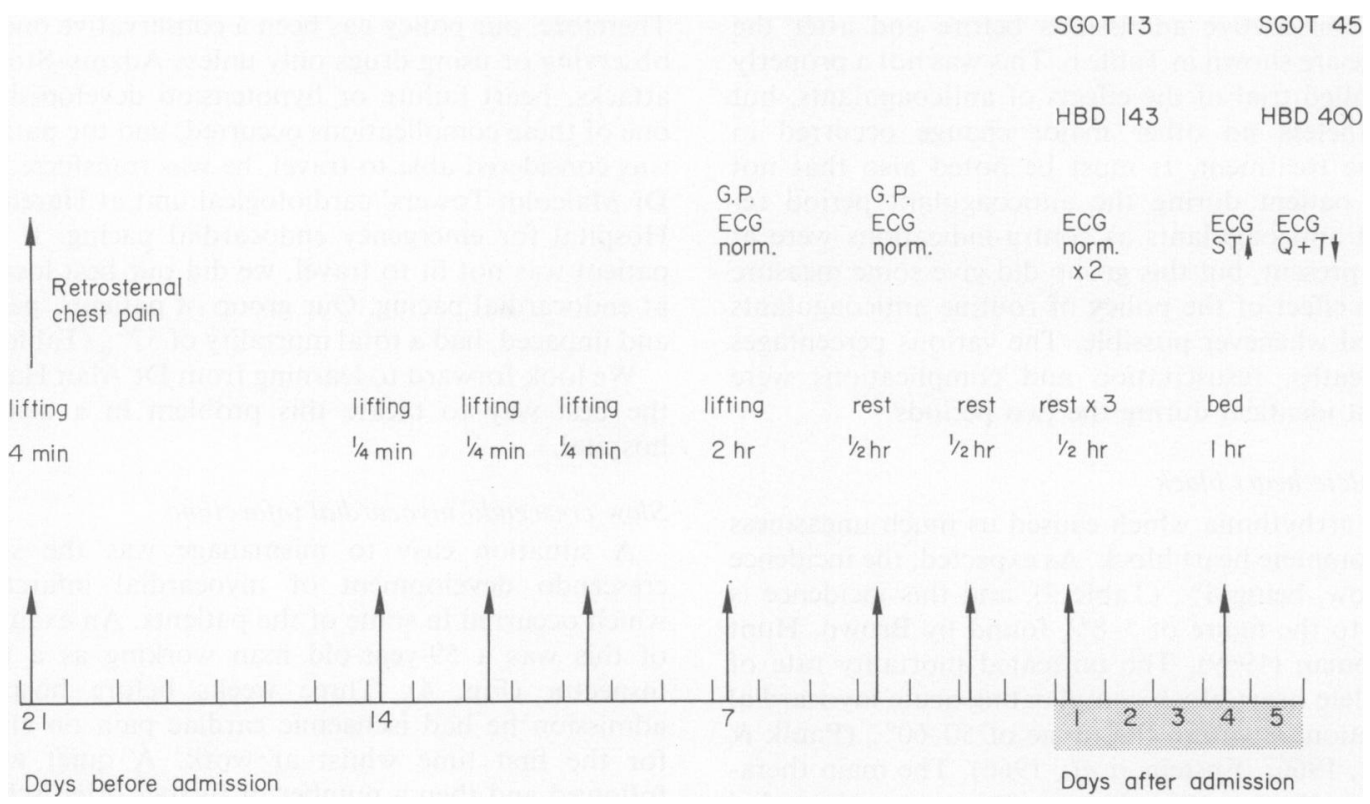

FIG. 4. Slow crescendo development of myocardial infarction. Normal values: SGOT $<20$ international units; HBD $<140$ international units.

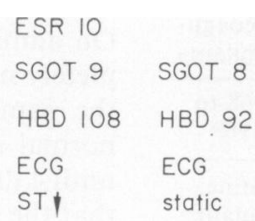

Walking,

severe

chest pain

$20 \mathrm{~min}$

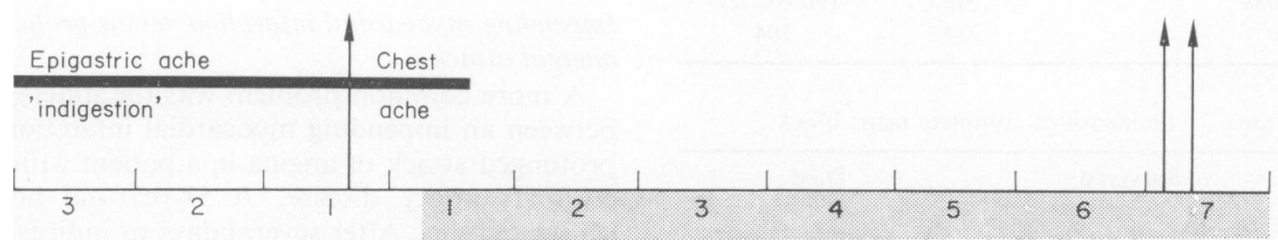

Days before and after admission 
precaution, her general practitioner sent her into hospital. The electrocardiogram showed slight depression of the S-T segment in leads $V_{5}$ and $V_{6}$ compatible with coronary artery disease. Erythrocyte sedimentation rate and serum enzymes were normal. Next day the repeat electrocardiogram was reassuringly stable and serum enzymes still normal. Early discharge for the patient was planned with the diagnosis of a prolonged attack of angina. Whilst pushing round the ward tea trolley she abruptly had cardiac arrest from ventricular fibrillation. This was corrected as also was a further attack $3 \mathrm{hr}$ later. Following these upsets full evidence of myocardial infarction then appeared on the electrocardiogram and in the serum enzyme tests.

\section{Acknowledgments}

This report is made on behalf of the physicians jointly involved with the working of the unit.

All the medical staff are greatly indebted to Sister E. Mendelssohn and her nurses for their unflagging and skilled professional support.

\section{References}

Beard, O.W., Hipp, H.R., Robins, M., TAYlor, J.S., EBerT, R.V. \& BERAN, L.G. (1960) Initial myocardial infarction among 503 Veterans. Five year survival. American Journal of Medicine, 28, 871.

Brown, R.W., Hunt, D. \& Sloman, J.G. (1969) The natural history of atrioventricular conduction defects in acute myocardial infarction. American Heart Journal, 78, 460.

Epstein, E.J., Coulshed, N., McKendrick, C.S., Clarke, J. \& KeARns, W.E. (1966) Artificial pacing by electrode catheter for heart block or asystole complicating acute myocardial infarction. British Heart Journal, 28, 546.

Goble, A.J., Sloman, G. \& Robinson, J.S. (1966) Mortality reduction in a coronary care unit. British Medical Journal, $1,1005$.

Honey, G.E. \& Truelove, S.C. (1957) Prognostic factors in myocardial infarction. Lancet, $\mathbf{i}, 1155$.
Jewitt, D.E., Balcon, R., Raferty, E.B. \& Oram, S. (1967) Incidence and management of supra-ventricular arrhythmias after acute myocardial infarction. Lancet, ii, 734.

KILlip, T. (1966) In The Curr ent Status of Intensive Coronary Care, American College of Cardiology-University of Pennsylvania Symposium (Ed. by L. E. Meltzer and J. R. Kitchell). Charles Press, New York.

Lawrie, D.M., Greenwood, T.W., Goddard, M., Harvey, A.C., Donald, K.W., Julian, D.G. \& Oliver, M.F. (1967) A coronary care unit in the routine management of acute myocardial infarction. Lancet, ii, 109.

Lown, B., Fakhro, A.M., Hood, W.B. \& Thorn, G.W. (1967) The coronaly care unit. New perspectives and directions. Journal of the American Medical Association, $199,188$.

McNeilly, R.H. \& Pemeerton, J. (1968) Duration of last attack of 998 fatal cases of coronary artery disease and its relation to possible cardiac resuscitation. British Medical Journal, 3, 139.

PAulk, E.A., JR \& Hurst, J.W. (1966) Complete heart block in acute myocardial infarction. A clinical evaluation of the intracardiac bipolar catheter pacemaker. American Journal of Cardiology, 17, 695.

Pentecost, B.L. \& Mayne, N.M.C. (1968) Results of a general hospital coronary care service. British Medical Journal, 1, 830.

Soott, M.E., Geddes, J.S., Patterson, G.C., Adgey, A.A.J. \& PANTRIDGe, J.F. (1967) Management of complete heart block complicating acute myocardial infarction. Lancet, ii, 1382.

Sowton, E. (1967) Cardiac pacemakers and pacing. Modern Concepts of Cardiovascular Disease, 36, 31 .

Spracklen, F.H.N., Besterman, E.M.M., Everest, M.S., Litchfield, J.W. \& Petrie, M. (1968) Late ventricular dysrhythmias after myocardial infarction. British Medical Journal, 4, 364.

Sutton, R., Chatterjee, K. \& Leatham, A. (1968) Heart block following acute myocardial infarction. Treatment with demand and fixed rate pacemakers. Lancet, ii, 645 .

Thomas, M., JewitT, D.E. \& Shillingford, J.P. (1968) Analysis of 150 patients with acute myocardial infarction admitted to an intensive care and study unit. British Medical Jcurnal, 1, 787.

Thomas, M. \& WocDgate, D. (1966) Effect of atropine on bradycardia and hypotension in acute myocardial infarction. British Heart Journal, 28, 409. 